\title{
Do age and education predict performance of older adults on the d2 Test?
}

\author{
Luis Henrique Paloski \\ Faculdade Meridional, RS, Brasil \\ Adriano Medeiros da Cunha \\ Pontificia Universidade Católica do Rio Grande do Sul, RS, Brasil \\ Camila Rosa de Oliveira \\ Faculdade Meridional, RS, Brasil \\ Marianne Farina \\ Valéria Gonzatti \\ Elisa Arrienti Ferreira \\ Manoela Ziebell de Oliveira \\ Irani Iracema de Lima Argimon \\ Tatiane Quarti Iragaray \\ Pontificia Universidade Católica do Rio Grande do Sul, RS, Brasil
}

\begin{abstract}
The objective of this study was to investigate the association of age and education in the performance of cognitively preserved older adults in the d2 Sustained-Attention Test, and to compare the results of different age groups and levels of schooling in this instrument. The sample was composed of 211 adults, 60 years of age or older, who were not institutionalized, and who completed a sociodemographic questionnaire, the Mini Mental State Examination, the Geriatric Depression Scale (short form), and the d2 Test. Data analysis was conducted using descriptive statistics, partial correlations, multiple linear regression and one-way ANOVA. The results of partial correlations and multiple linear regression showed that age and years of schooling demonstrated significant associations with all $\mathrm{d} 2$ Test scores, with age being the predictive variable that showed the greatest influence on the performance of the older adults. Comparison of performance in the $\mathrm{d} 2$ Test among the six groups according to the distribution by age group (60-69 years and 70 years or more) and by levels of schooling (primary, secondary and higher) showed that younger adults with a higher level of schooling scored better on the $\mathrm{d} 2$ Test, suggesting the need for normative data studies for this population.
\end{abstract}

Keywords: Elderly; Performance; d2 Test; Sustained Attention.

\section{Idade e escolaridade são preditoras de desempenho de adultos idosos no Teste d2?}

\section{Resumo}

O objetivo deste estudo foi investigar a associação da idade e da escolaridade com o desempenho de idosos cognitivamente preservados no Teste d2 de Atenção Concentrada, além de comparar os resultados de diferentes grupos etários e de níveis de escolaridade nesse instrumento. Participaram 211 adultos com idade igual ou superior a 60 anos, não institucionalizados, que responderam a uma ficha de dados sociodemográficos, ao Mini Exame do Estado Mental, à Escala de Depressão Geriátrica (versão reduzida), e ao Teste d2. A análise dos dados foi conduzida por meio de estatística descritiva, correlações parciais, regressão linear múltipla e ANOVA de uma via (one-way ANOVA). Os resultados das correlações parciais e da regressão linear múltipla revelaram que a idade e os anos de escolaridade demonstraram associações significativas com todos os escores do Teste d2, sendo a idade a variável preditora que demonstrou maior influência no desempenho dos idosos. A comparação de desempenho no teste d2 entre os seis grupos conforme distribuição por faixa etária (60-69 anos e 70 anos ou mais) e por níveis de escolaridade (fundamental, médio e superior) demonstrou que os idosos mais jovens e com maior nível de escolaridade apresentam melhores pontuações no Teste d2, sugerindo a necessidade de estudos de dados normativos para essa população.

Palavras-chave: Idosos; Desempenho; Teste d2 - Atenção concentrada; Atenção sustentada.

\section{Edad y escolaridad son preditoras de rendimiento de adultos mayores en la Test d2? \\ Resumen}

El objetivo de este estudio fue investigar la asociación de la edad y la escolaridad con el rendimiento de ancianos cognitivamente preservados en el Test de Atención Sostenida d2, y comparar los resultados de diferentes grupos etarios y de niveles de escolaridad en ese instrumento. La muestra fue compuesta por 211 adultos con edad igual o superior a 60 años, no institucionalizados, que respondieron a una ficha de datos sociodemográficos, al Mini Examen del Estado Mental, a la Escala de Depresión Geriátrica (versión reducida), y al Test d2. El análisis de los datos fue conducido por medio de estadística descriptiva, correlaciones parciales, regresión lineal múltiple y ANOVA de una vía (one-way ANOVA). Los resultados de las correlaciones parciales y de la regresión lineal múltiple revelaron que la edad y los años de escolaridad demostraron asociaciones significativas con todos las puntuaciones del Test d2, siendo la edad la variable predictora que demostró mayor influencia en el rendimiento de los adultos mayores. La comparación de desempeño en el Test d2 entre los seis grupos según distribución por grupo de edad (60-69 años y 70 años o más) y por niveles de escolaridad (fundamental, media y superior) demostró que los ancianos más jóvenes y con mayor nivel de escolaridad presentan mejores puntuaciones en el Test d2, sugiriendo la necesidad de estudios de datos normativos para esa población.

Palabras clave: Ancianos; Rendimiento; Test d2; Atención sostenida. 


\section{Introduction}

Attention is a cognitive function that allows an individual to process a limited amount of information obtained and made available through the sensory organs, memory and other cognitive and physiological processes (Sternberg, 2006). There are different types of attention. One of them is sustained attention, defined as the ability of an individual to keep focus exclusively on only one stimulus and eliminate all others (Rueda \& Monteiro, 2013).

Sustained attention has a proven, direct relationship to other cognitive functions, such as memory, orientation, perception and executive functions (Lezak, Howieson, Bigler, \& Tranel, 2013; Lopes, Ziemnczak, Nascimento, \& Argimon, 2015; Strauss, Sherman, \& Spreen, 2006; Sohlberg \& Mateer, 2009). Despite its relevance, this function has been the subject of relatively little scientific research (Lezak et al., 2013), especially in the elderly population.

Elderly people experience cognitive alterations as part of the typical aging process. Reductions in processing speed and in the ability to keep and focus attention are frequent (Fernandes \& Santos, 2015; Lezak et al., 2013; Pesce, Guidetti, Baldari, Tessitore, \& Capranica, 2005; Rueda, Noronha, Sisto, \& Bartholomeu, 2008; Rueda \& Monteiro, 2013; Paula, Silva, Fuentes, \& Malloy-Diniz, 2013). This reduction is probably due to aging of the brain, which initially affects the prefrontal cortex, the main area responsible for attention (Lezak et al., 2013; Lopes, Ziemnczak, Nascimento, \& Argimon, 2015; Paula, Silva, Fuentes, \& Malloy-Diniz, 2013). Decreased attention in the elderly may also be influenced by the presence of mood disorders, such as depression, which often occurs in this population (Lezak et al., 2013; Mattos \& Junior, 2010; Paula et al., 2013; Sohlberg \& Mateer, 2009).

Sustained attention may affect the memory performance of older adults (Parente \& Taussik, 2002). Considering that sustained attention is directly related to memory performance (Kim et al., 2011), assessment of this function in a suitable manner, with relevant normative data for this population, is particularly relevant to (Fernandes \& Santos, 2015; Neri \& Yassuda, 2008). The literature supports this assumption (Carreiro et al., 2015; Rueda, 2010; Werlang, 2012). Therefore, this study aimed to investigate the association of age and education level with performance of older adults on the $\mathrm{d} 2$ Test, and to compare the performance of different age and educational groups.

\section{Method}

\section{Design}

Cross-sectional study.

\section{Participants}

Participants were 211 older adults, recruited for convenience, from a metropolitan region in the South of Brazil, aged between 60 and 94 years $(M=69.83$; $S D=6.77)$, with 1 to 24 years of formal schooling $(M=11.02 ; S D=5.11) ; 87 \%$ were women $(n=183)$. The inclusion criteria were age 60 years or older, not being illiterate, and not being a resident of a long-term care facility. The exclusion criteria were: 1) scores suggestive of cognitive decline on the Mini Mental State Examination - MMSE (Folstein, Folstein, \& McHugh, 1975, adapted by Chaves \& Izquierdo, 1992) according to cutoff points for education suggested by Kochhann, Varela, Lisboa and Chaves (2010) for older adults from Southern Brazil ( $<22$ for 1-5 years of study, $<23$ for 6 - 11 , and $<24$ for 12 or more); 2 ) scores $\geq 6$ on the Geriatric Depression Scale, short form - GDS-15 (Yesavage et al., 1982-1983, adapted by Almeida \& Almeida, 1999); 3) presence of uncorrected primary sensory problems at the time of the evaluation (use of glasses or hearing aids, for example); 4) history of neurological and/or psychiatric disorders, investigated through self-report; and 5) failure to complete all study instruments.

\section{Instruments}

Sociodemographic Data. The sociodemographic data form collected the following variables: age, gender, marital status, education, and economic classification criteria (Associação Brasileira de Empresas de Pesquisa, 2015). It also investigated residential conditions, occupation, leisure activities, physical and mental health, medications used, smoking and drinking habits, physical activities and participation in social groups.

Mini Mental State Examination (MMSE). The MMSE is a cognitive screening instrument (Folstein, Folstein, \& McHugh, 1975; Bertolucci et al., 1994). It was used with the purpose of excluding potential participants with scores that suggested dementia.

Geriatric Depression Scale, short form (GDS-15). The GDS-15 is a measure used to identify and quantify depressive symptoms in the elderly. Fifteen items compose the short version in Portuguese (Yesavage et al., 1982-1983). This scale was used with the purpose of excluding potential participants with depressive symptoms, with a cutoff of 6 points (Paradela, Lourenço, \& Veras, 2005).

d2 Test. The $\mathrm{d} 2$ is a cancellation test which measures the level of concentrated visual attention. It may be applied in individual or collective form (Brickenkamp,1962; 2002; Mattos \& Júnior, 2010; Michels \& Gonçalves, 2014; Rueda, 2011). This instrument is used in different contexts, such as driving 
school tests, organizations and in the clinical setting (Brickenkamp, 2002, Rueda, 2011). It is composed of 14 lines, each one with 47 symbols. The respondent has 20 seconds to find and mark three defined symbols among mixed symbols in each line (Brickenkamp, 2002; Michels \& Gonçalves, 2014). Results of the d2 Test are mainly verified via five scores: 1) Total Number of Characters Processed (TN), which indicates the quantitative performance of the examinee and may indicate speed in activities that require attention; 2) Total Errors (E), which comprises the sum of omitted signs and wrong signs ticked, and evaluates sustained attention,; 3) Percentage of Errors (E\%), defined by the formula $(100 \times \mathrm{E} / \mathrm{TN})$, which indicates the association between speed and accuracy; 4) Total Correctly Processed (TN-E), the total number of correct answers (raw score minus total errors), which gives the overall performance; and 5) Fluctuation Rate (FR), which demonstrates fluctuation in the work rate of concentration capacity. This is checked on the line in which the respondent examined the highest number of items and on the line in which they examined the lowest number; the lowest number is then subtracted from from the highest. The distribution of errors (DE) committed in the first lines ( 1 to 4 ), in the middle lines (5 to 10 ) and in the final lines (11 to 14) can be analyzed (Brickenkamp, 2002).

\section{Data Collection Procedure}

The relevant institutional Ethics Committee approved the study (CAAE: 14769713.1.0000. 5336). Social groups for older adults in the Porto Alegre Metropolitan Area (universities or community centers, for example) were contacted. Participants were assessed individually in meetings that lasted approximately one hour, conducted between the years 2012 and 2013 at the social centers, in rooms free of visual and/or auditory distracting stimuli. Trained psychologists and psychology students conducted the interviews for data collection. The tests were corrected and analyzed by trained psychologists; $\mathrm{d} 2$ Test correction and analysis was computer-based.

\section{Data Analysis Procedure}

Descriptive statistics such as average scores, standard deviation, median and percentages were calculated. Data distribution was analyzed using the Kolmogorov-Smirnov test. Associations between the d2 Test scores (TN, E, E\%, TN-E, and FR), age and years of study were investigated by partial correlations, controlling for education (years) and age (years). The strength of the associations was interpreted based on Cohen's 1988 classification, which defines values $\leq .2$ as a small effect size, $\leq .5$ as an medium effect size and $\geq .6$ as a large effect size. To investigate potential predictive variables for performance in $\mathrm{d} 2$ Test scores (dependent variable), multiple linear regression analysis with the stepwise method was used. Age and years of study were defined as the predictor variables (independent variables). The presence of residues and collinearity was verified by the Durbin-Watson test. One-way analysis of variance (ANOVA) with Scheffe's post-hoc test was performed to verify differences in performance in the $\mathrm{d} 2$ Test between two age groups (60-69 years and 70 years or more), further subdivided into three levels of education: primary (1-9 years of study), secondary (10-12 years of study) and higher (13 years or more of study). This classification was defined based on the Brazilian education system. Results with $p \leq .05$ were considered significant. Analyses were conducted using IBM SPSS Statistics for Windows, Version 22.0.

\section{Results}

Table 1 presents means, standard deviations, medians and ranges for MMSE, the GDS-15, and d2 Test scores in the overall sample. Results for the association and comparative analyses will be presented separately.

\section{Analysis of association between $\mathrm{d} 2$ Test scores, age and education}

The results of partial correlations correlation analysis are shown in Table 2. Age and education variables showed significant associations with all $\mathrm{d} 2$ Test scores, although the strength of the associations ranged from weak to moderate. Regarding age, results showed weak, negative correlations with $\mathrm{d} 2 \mathrm{TN}$ score and TN-E score. Associations with other $\mathrm{d} 2$ scores (E, E\%, FR and distribution of errors) were weakly positive. Regarding education, results showed a moderate, negative association with the $\mathrm{E} \%$ score. All other correlations were weak, some negative (E, FR and distribution of errors) and some positive (TN and TN-E).

Table 3 presents the multiple linear regression models for each of the $\mathrm{d} 2$ Test scores. The lowest variance explained was obtained by the $\mathrm{TN}$ score model (6\%), and the highest was obtained by the $\mathrm{E} \%$ score model $(20 \%)$. Although age and years of study contributed to all d2 Test scores, the standardized scores suggest that age was a predictor of greater influence on TN, E and FR performance, while years of study were more influential predictors of $\mathrm{E} \%$ and TN-E performance. 
TABLE 1

Descriptive Statistics for MMSE, GDS-15, and d2 Test Scores

\begin{tabular}{lcccc}
\hline & \multicolumn{3}{c}{$\begin{array}{c}\text { Participants } \\
(n=211)\end{array}$} \\
\cline { 2 - 5 } & $M$ & $S D$ & Median & Range \\
\hline GDS-15 (score) & 2.26 & 1.26 & 6.00 & $0-5$ \\
MMSE (score) & 27.63 & 1.97 & 28.00 & $22-30$ \\
d2 Test (scores) & & & \\
Total number of characters processed (TN) & 290.99 & 103.57 & 280.00 & $70-608$ \\
Total errors (E) & 35.45 & 42.00 & 20.00 & $0-244$ \\
Percentage of errors (E\%) & 12.05 & 11.33 & 7.43 & $0.00-43.64$ \\
Total correctly processed (TN-E) & 254.64 & 94.26 & 253.00 & $22-499$ \\
Fluctuation rate (FR) & 16.44 & 8.43 & 14.00 & $6-46$ \\
Error distribution (lines 1 to 4) & 8.98 & 10.32 & 6.00 & $0-71$ \\
Error distribution (lines 5 to 10) & 15.37 & 18.50 & 9.00 & $0-102$ \\
Error distribution (lines 11 to 14) & 11.03 & 14.81 & 6.00 & $0-83$ \\
\hline
\end{tabular}

GDS-15: Geriatric Depression Scale, short form; MMSE: Mini Mental State Examination.

TABLE 2

Partial Correlations between Age, Education, and the d2 Test Scores

\begin{tabular}{lcc}
\hline & \multicolumn{2}{c}{ Participants $(n=211)$} \\
\cline { 2 - 3 } & $\begin{array}{c}\text { Age } \\
\text { (years) }\end{array}$ & $\begin{array}{c}\text { Education } \\
\text { (years) }\end{array}$ \\
\hline Total number of characters & $-.184^{* *}$ & $.160^{*}$ \\
processed (TN) & $.154^{*}$ & $-.198^{* *}$ \\
Total errors (E) & $.287^{* * *}$ & $-.328^{* * *}$ \\
Percentage of errors (E\%) & $-.281^{* * *}$ & $.286^{* * *}$ \\
Total correctly processed (TN-E) & $.278^{* * *}$ & $-.241^{* * *}$ \\
Fluctuation rate (FR) & $.160^{*}$ & $-.174^{* *}$ \\
Error distribution (lines 1 to 4) & $.140^{*}$ & $-.196^{* *}$ \\
Error distribution (lines 5 to 10) & $.145^{*}$ & $-.192^{* *}$ \\
\hline Error distribution (lines 11 to 14) &
\end{tabular}

a Partial correlation controlling for education (years) variable; ${ }^{b}$ Partial correlation controlling for age (years) variable. $* \leq .05 ; * * p \leq .01 ; * * * p \leq .001$.

\section{Comparison analyzes among age groups stratified by educational levels}

Table 4 presents the results of univariate analysis to compare performance on the $\mathrm{d} 2$ test scores in the six study groups, divided by age (60-69 and 70+) and educational level (primary, secondary or higher education). The group aged 60-69 with higher education obtained significantly higher TN scores than the groups aged $70+$ with primary $\left(p_{\text {post hoc }}=.050\right)$ and secondary $\left(p_{\text {post hoc }}=.008\right)$ education. Regarding the $\mathrm{E} \%$ score, the group aged $70+$ with primary education alone obtained significantly lower scores than the groups aged 60-69 with secondary $\left(p_{\text {post hoc }} \leq .001\right)$ and higher $\left(p_{\text {post hoc }}=.050\right)$ education and the group aged $70+$ with higher education $\left(p_{\text {post hoc }}=.037\right)$.

TABLE 3

Multiple Linear Regression Models for d2 Test Main Scores

\begin{tabular}{|c|c|c|c|c|c|}
\hline & $R^{2} a$ & $F$ & $b$ & $t$ & $p$ \\
\hline \multicolumn{6}{|c|}{ Total number of characters processed (TN) } \\
\hline Age (years) & .060 & 7.736 & -.184 & -2.700 & .008 \\
\hline Education (years) & & & .158 & 2.330 & .021 \\
\hline \multicolumn{6}{|l|}{ Total errors $(E)$} \\
\hline Age (years) & .073 & 8.180 & .152 & -2.909 & .004 \\
\hline Education (years) & & & -.197 & 2.244 & .026 \\
\hline \multicolumn{6}{|c|}{ Percentage of errors (E\%) } \\
\hline Age (years) & .196 & 26.561 & .272 & 4.319 & $\leq .001$ \\
\hline Education (years) & & & -.315 & -5.002 & $\leq .001$ \\
\hline \multicolumn{6}{|c|}{ Total correctly processed (TN-E) } \\
\hline Age (years) & .168 & 22.152 & -.270 & -4.223 & $\leq .001$ \\
\hline Education (years) & & & .275 & 4.305 & $\leq .001$ \\
\hline \multicolumn{6}{|l|}{ Fluctuation Rate (FR) } \\
\hline Age (years) & .142 & 18.432 & .272 & 4.181 & $\leq .001$ \\
\hline Education (years) & & & -.233 & -3.582 & $\leq .001$ \\
\hline
\end{tabular}

$R^{2} a$ : $\mathrm{R}^{2}$ adjusted. 
TABLE 4

d2 Test Normative Data for the Elderly Population according to Age and Level of Education

\begin{tabular}{|c|c|c|c|c|c|c|c|c|c|c|c|c|c|c|}
\hline \multirow{3}{*}{ Education group } & \multicolumn{6}{|c|}{$60-69$} & \multicolumn{6}{|c|}{$70+$} & \multirow{3}{*}{$F$} & \multirow{3}{*}{$p$} \\
\hline & \multicolumn{2}{|c|}{$\begin{array}{l}\text { Elementary } \\
\quad(n=39)\end{array}$} & \multicolumn{2}{|c|}{$\begin{array}{l}\text { Middle } \\
(n=29)\end{array}$} & \multicolumn{2}{|c|}{$\begin{array}{l}\text { Higher } \\
(n=41)\end{array}$} & \multicolumn{2}{|c|}{$\begin{array}{l}\text { Elementary } \\
\quad(n=46)\end{array}$} & \multicolumn{2}{|c|}{$\begin{array}{l}\text { Middle } \\
(n=24)\end{array}$} & \multicolumn{2}{|c|}{$\begin{array}{l}\text { Higher } \\
(n=32)\end{array}$} & & \\
\hline & $M$ & $S D$ & $M$ & $S D$ & $M$ & $S D$ & $M$ & $S D$ & $M$ & $S D$ & $M$ & $S D$ & & \\
\hline Age (years) & 64.74 & 3.02 & 64.52 & 2.76 & 64.37 & 2.84 & 76.20 & 5.32 & 77.04 & 5.25 & 73.31 & 3.08 & & \\
\hline Education (years) & 6.23 & 1.91 & 11.07 & .65 & 16.98 & 2.63 & 5.70 & 2.22 & 11.17 & .38 & 16.75 & 1.98 & & \\
\hline \multicolumn{15}{|l|}{ d2 Test (scores) } \\
\hline $\mathrm{TN}$ & 275.03 & 96.73 & 306.03 & 103.24 & 343.27 & 88.21 & 271.24 & 91.98 & 240.17 & 91.78 & 296.31 & 127.44 & 4.202 & $\leq .001$ \\
\hline $\mathrm{E}$ & 37.36 & 39.08 & 26.59 & 41.71 & 23.41 & 39.23 & 52.26 & 40.57 & 32.29 & 42.36 & 34.78 & 45.82 & 2.541 & .300 \\
\hline $\mathrm{E} \%$ & 13.11 & 10.35 & 8.01 & 10.52 & 6.40 & 7.63 & 19.45 & 12.90 & 12.01 & 9.97 & 11.06 & 10.30 & 7.956 & $\leq .001$ \\
\hline TN-E & 237.74 & 79.52 & 279.59 & 89.37 & 319.88 & 79.94 & 214.67 & 87.73 & 207.88 & 69.98 & 261.53 & 107.21 & 8.847 & $\leq .001$ \\
\hline FR & 16.13 & 8.94 & 13.86 & 6.14 & 13.59 & 5.31 & 21.76 & 9.98 & 17.13 & 8.76 & 14.63 & 6.96 & 6.162 & $\leq .001$ \\
\hline ED 1-4 & 8.54 & 7.10 & 8.03 & 12.11 & 6.27 & 11.42 & 13.02 & 8.54 & 9.04 & 9.70 & 7.97 & 12.10 & 2.161 & .060 \\
\hline ED 5-10 & 16.90 & 18.97 & 10.97 & 17.07 & 9.95 & 16.74 & 22.57 & 19.90 & 13.42 & 16.56 & 15.59 & 18.33 & 2.628 & .250 \\
\hline ED 11-14 & 11.69 & 14.54 & 7.59 & 13.30 & 7.15 & 11.99 & 16.43 & 15.75 & 10.88 & 17.20 & 10.69 & 15.08 & 2.181 & .058 \\
\hline
\end{tabular}

TN: Total number of characters processed; E: Total errors; E\%: Percentage of errors; TN-E: Total correctly processed; FR: Fluctuation rate; ED: Error distribution. Educational groups correspond to primary ( 1 to 9 years of formal study), secondary (10 to 12 years of formal study), and higher ( 13 years or more of formal study) education.

In the TN-E score, the group aged 60-69 with higher education scored significantly higher than the same age group with primary education alone $\left(p_{\text {post hoc }}=.004\right)$ and than the groups aged $70+$ with primary $\left(p_{\text {post hoc }} \leq .001\right)$ and secondary $\left(p_{\text {post hoc }} \leq .001\right)$ education. Finally, in the FR score, the group aged $70+$ with primary education alone obtained significantly lower scores than the groups aged 60-69 with secondary $\left(p_{\text {post hoc }} \leq .005\right)$ and higher $\left(p_{\text {post hoc }} \leq .001\right)$ education and than the group aged $70+$ with higher education $\left(p_{\text {post hoc }}=.011\right)$. There were no significant differences in performance between groups in the $\mathrm{E}$ and error distribution scores.

\section{Discussion}

The purpose of this study was to investigate the association of age and education with performance on the $\mathrm{d} 2$ Sustained-Attention Test in older adults, and to compare the performance of different age groups, divided by schooling, in this population. The main finding was that age and education showed significant associations with all $\mathrm{d} 2$ Test scores. Thus, one can conclude that sustained-attention performance decreases as age increases, and that older adults with a higher level of education perform better.

There was a negative correlation between age and $\mathrm{d} 2$ Test net score, which suggests that, the more advanced the age, the worse the level of sustained attention. This finding is corroborated by previous studies which identified that, as age increases, processing speed slows down and the quality of responses may also decrease (Fernandes \& Santos, 2015; Rueda et al., 2008; Rueda, Javier \& Monteiro, 2013; Pesce et al., 2005), which probably leads to lower levels of attention.

Therefore, age had the highest influence on the performance of older adults in the $\mathrm{d} 2$ Test (TN, E, and FR). As age increases, there is a decrease in attention level due to natural aging of the brain, especially in the prefrontal cortex, which is the main area responsible for the attentional process (Custódio, Malaquias Júnior, \& Voos, 2010). Thus, one may infer that, as age increases, the sustained attention level declines even in healthy older people.

Furthermore, it has been observed that education level is a protective factor for sustained attention. Participants with a higher level of education obtained higher scores in the $\mathrm{d} 2$ Test, corroborating these previous studies (Cecato, Fiorese, Bartholomeu, \& Martinelli, 2011; Fernandes \& Santos, 2015). In addition, education correlated positively with the net score. It is believed that people with more years of education perform better on this cancellation test because they are literate and familiar with letters (Brewster et al., 2014; Silva, Cardoso, \& Fonseca, 2012). Other studies have observed that education works as a protective factor for cognitive capacities during the aging process (Argimon, 2002; Oliveira et al., 2015). Previous research demonstrated that the lower the level of education, the worse the cognitive performance, including on attention (Mello, Haddad, 
\& Dellaroza, 2011). A lower level of education is also associated with greater cognitive impairment (Argimon \& Stein, 2005; Oliveira, et al., 2015).

In other way, results pointed out that higher age and fewer years of education were associated to worse performance in sustained attention. These results suggest there is a need for better understanding of the influence of these variables on other cognitive abilities, since sustained attention, when altered, may impair memory and learning. The variables age and education may interfere significantly with attentional tasks, which is supported by the literature. The decrease of sustained attention with advancing age may be related to alterations that occur in the prefrontal cortex, which is one of the structures involved in the attentional process (Lezak et al., 2013).

The influence of education on healthy cognitive abilities in the elderly has been noted in several studies (Meijer, Van Boxtel, Van Gerven, Van Hooren, \& Jolles, 2009; Strout \& Howard, 2012), suggesting that years of education may be one of the components of the cognitive reserve (Stern, 2009, 2012). Therefore, older adults who have completed more years of education may have lower odds of cognitive deterioration compared to those with fewer years of education (Contador, Bermejo-Pareja, Del Ser, \& Benito-León, 2015).
Investigation of the influence of age and education on older adults' performance in the d2 SustainedAttention Test and the gathering of normative data for this population showed how relevant and adequate this instrument was to assess sustained attention in the elderly, as its sensitivity is able to detect neurodevelopmental aspects and educational characteristics. The findings presented herein may contribute to the professional practice of psychological assessment by ensuring the adequacy and precision of this instrument for clinical use in the elderly population. It is known that studies investigating normative data for psychological instruments aim at increasing the evidence of validity and reliability for a determined population, as they consider the cultural, social and economic reality (Alchieri \& Cruz, 2014; Fachel \& Camey, 2000; Hutz, Bandeira, \& Trentini, 2015).

We suggest that additional studies be conducted to obtain normative data about the performance of older adults in sustained attention tests, as the lack of studies focusing on the population over 60 is evident. Limitations of the present study include the small number of men in the sample and the fact that all participants were from Rio Grande do Sul, which limits the generalizability of data for other regions of the country.

\section{References}

Associação Brasileira de Empresas de Pesquisa. (2015). Critério Brasil. Recuperado de <http://www.abep.org>.

Alchieri, J. C. \& Cruz, R. M. (2014). Avaliação psicológica: conceitos, método e instrumentos. São Paulo: Casa do Psicólogo.

Almeida, O. P. \& Almeida, S. A. (1999). Confiabilidade da versão brasileira da Escala de Depressão em Geriatria (GDS) versão reduzida. Arquivos de Neuro-Psiquiatria, 57(2B), 421-426. 10.1590/S0004-282X1999000300013

Argimon, I. L. (2002). Desenvolvimento cognitivo na terceira idade. Tese de doutorado, Pontifícia Universidade Católica do Rio Grande do Sul. Porto Alegre.

Argimon, I. L. \& Stein, L. M. (2005). Habilidades cognitivas em indivíduos muito idosos: um estudo longitudinal. Cadernos de Saúde Pública, 21(1), 64-72. 10.1590/S0102-311X2005000100008

Bertolucci, P. H., Brucki, S., Campacci, S. R., \& Juliano, Y. (1994). O Mini-Exame do Estado Mental em uma população geral: impacto da escolaridade. Arquivos de Neuropsiquiatria, 52(1), 1-7. 10.1590/S0004-282X1994000100001

Brewster, P. W., Melrose, R. J., Marquine, M. J., Johnson, J. K., Napoles, A., MacKay-Brandt, A., ... \& Mungas, D. (2014). Life experience and demographic influences on cognitive function in older adults. Neuropsychology, 28(6), 846. 10.1037/neu0000098

Brickenkamp, R. (1962). Aufmerksamkeits-Belastungs-Test Handanweisung d-2 [Attention capacity test manual d-2]. Oxford, England: C. J. Hogrefe.

Brickenkamp, R. (2002). Teste d2: Atenção concentrada. Manual/Padronização Brasileira - Irai Cristina Boccato Alves. São Paulo: Casa do Psicólogo.

Carreiro, L. R. R., Reppold, C. T., de Castro Mariani, M. M., Lellis, V. R. R., Dias, N. M., Fioravanti-Bastos, A. C. M., \& Seabra, A. G. (2015). Habilidades cognitivas ao longo do desenvolvimento: contribuições para o estudo da atenção concentrada. Psicologia: Teoria e Prática, 17(2), 153-170. 10.15348/1980-6906/psicologia.v17n2p153-170

Cecato, J. F., Fiorese, B., Bartholomeu, L. L., \& Martinelli, J. E. (2015). Avaliação da atenção em idosos. Encontro: Revista de Psicologia, 14(20), 79-88.

Chaves, M. L. \& Izquierdo, I. (1992). Differential diagnosis between dementia and depression: A study of efficiency increment. Acta Neurologica Scandinavica, 11, 412-429. 10.1111/j.1600-0404.1992.tb06032.x 
Cohen, J. (1988). Statistical power analysis for the behavioral sciences. Aarhus: Hillsdale Erlbaum.

Contador, I., Bermejo-Pareja, F., Del Ser, T., \& Benito-León, J. (2015). Effects of education and word reading on cognitive scores in a community-based sample of Spanish elders with diverse socioeconomic status. Journal of clinical and experimental neuropsychology, 37(1), 92-101. 10.1080/13803395.2014.989819

Custódio, E. B., Malaquias Júnior, J., \& Voos, M. C. (2010). Relação entre cognição (função executiva e percepção espacial) e equilíbrio de idosos de baixa escolaridade. Fisioterapia \& Pesquisa, 17(1), 46-51. 10.1590/S180929502010000100009

Fashel, J. M. G. \& Camey, S. (2003). Avaliação Psicométrica: a qualidade das medidas e o entendimento dos dados. In: Cunha, J. A. Psicodiagnóstico-V (pp. 158-170). Porto Alegre: ArtMed.

Fernandes, E. S. \& Santos, A. A. A. (2015). Testes de Atenção para Idosos: relações com idade, escolaridade e moradia. Psico, 46(1), 110-119. 10.15448/1980-8623.2015.1.17281

Folstein, M. F., Folstein, S. E., \& McHugh, P. R. (1975). Mini-mental state. A practical method for grading the cognitive state of patients for the clinician. Journal of Psychiatric Research, 12(3), 189-198. 10.1016/0022-3956(75)90026-6

Hutz, C. S., Bandeira, D. R., \& Trentini, C. M. (2015). Psicometria. Porto Alegre: Artmed.

Kim, S., Park, M. H., Han, S. H., Na, H. R., Cho, S., Choi, M. S., ..., \& Park, K. W. (2011). Validation analysis of the attention questionnaire scale. Journal of Alzhimer's Disease, 24(2), 393-402. 10.3233/JAD-2011-100660

Kochhann, R., Varela, J. S., Lisboa, C. S. M., \& Chaves, M. L. F. (2010). The Mini Mental State Examination review of cutoff points adjusted for schooling in a large Southern Brazilian sample. Dementia \& Neuropsychologia, 4(1), 35-41. 10.1590/S1980-57642010DN40100006

Lezak, M. D., Howieson, D. B., Bigler, E. D., \& Tranel. (2013). Neuropsychological Assessment. New York: Oxford University Press.

Lopes, M. F. L., Ziemnczak, V., Nascimento, R. F. L., \& Argimon, I. I. L. (2015). Funções executivas: a regência de uma orquestra. In D. H. Argimon, I. I. L, Esteves, C. S., \& Wendt, G. W. (Orgs.). Ciclo Vital Perspectivas Contemporâneas em Avaliação e Intervenção (pp. 71-82). Porto Alegre: EDIUCRS.

Mattos, P. \& Junior, C. (2010). Avaliação Cognitiva de Idosos: Envelhecimento e Comportamento Cognitivo Leve. In: Malloy, L. Fuentes, D. Mattos, P. e Abreu, N. (Orgs.). Avaliação Neuropsicológica (pp. 247-253). Porto Alegre: Artmed.

Meijer, W. A., Van Boxtel, M. P., Van Gerven, P. W., van Hooren, S. A., \& Jolles, J. (2009). Interaction effects of education and health status on cognitive change: A 6-year follow-up of the Maastricht Aging Study. Aging \& Mental Health, 13(4), 521-529. 10.1080/13607860902860821

Mello, B. L. D., Haddad, M. D. C. L., \& Dellaroza, M. S. G. (2011). Avaliação cognitiva de idosos institucionalizados. Health Science, 34(1), 95-102. 10.4025/actascihealthsci.v34i1.7974

Michels, M. S. \& Gonçalves, H. A. (2014). Funções executivas em um caso de TDAH adulto: a avaliação neuropsicológica auxiliando o diagnóstico. Neuropsicologia Latinoamericana, 6(2), 35-41.

Neri, A. L. \& Yassuda, M. S. (2008). Velhice bem-sucedida: aspectos afetivos e cognitivos (3a ed.). Campinas: Papirus

Oliveira, E. M. D., Silva, H. S. D., Lopes, A., Cachioni, M., Falcão, D. V. D. S., Batistoni, S. S. T., ... \& Yassuda, M. S. (2015). Atividades Avançadas de Vida Diária (AAVD) e desempenho cognitivo entre idosos. Psico-USF, 20(1), 109-120.

Paradela, E. M. P., Lourenço, R. A., \& Veras, R. P. (2005). Validação da escala de depressão geriátrica em um ambulatório geral. Revista de Saúde Pública, 39(6), 918-923.

Parente, M. A. M. P. \& Taussik, I. (2002). Neuropsicologia, distúrbios de memória e esquecimentos benignos. Revista Eletrônica de Jornalismo. Recuperado de: <http://www.luzimarteixeira.com.br/wp-content/uploads/2011/04/tapoiomotivacao-no-envelhecimento-4.pdf>.

Paula, J., Silva, K., Fuentes, D., \& Malloy-Diniz, L. (2013). Funções Executivas e Envelhecimento. In: Malloy-Diniz, L. Fuentes, D e Cosenza, R. (Orgs.). Neuropsicológica do Envelhecimento: Uma Abordagem Multidimensional (pp. 226-242). Porto Alegre, RS: Artmed.

Pesce, C., Guidetti, L., Baldari, C., Tessitore, A., \& Capranica, L. (2005). Effects of aging on visual attentional focusing. Gerontology, 51(4), 266-276. 10.1159/000085123

Rueda, F. J. M. \& Montero, R. (2013). Bateria Psicológica para Avaliação da Atenção (BPA): desempenho de diferentes faixas etárias. Psico-USF, Bragança Paulista, 18(1), 99-108.

Rueda, F. J. M. (2010). Relação entre os testes de atenção concentrada (TEACO-FF) e de atenção dividida (AD). Psicologia Argumento, 28(62), 225-234.

Rueda, F. J. M. (2011). Desempenho no teste de atenção dividida como resultado da idade das pessoas. Estudos de Psicologia (Campinas), 28(2), 251-259. 10.1590/S0103-166X2011000200012

Rueda, F. J. M., Noronha, A. A. P., Sisto, F. F., \& Bartholomeu, D. (2008). Evidência de validade de construto para o Teste de Atenção Sustentada. Psicologia: Ciência e Profissão, 28(3), 494-505.

Silva, R. F. C., de Oliveira Cardoso, C., \& Fonseca, R. P. (2012). Diferenças quanto à escolaridade em adultos no desempenho no Teste de Cancelamento dos Sinos. Estudos de Psicologia, 17(2), 215-222.

Sohlberg, M. M. \& Mateer, C. A. (2009). Reabilitação cognitiva: uma abordagem neuropsicológica integrativa. Santos: Editora Santos. 
Stern, Y. (2009). Cognitive reserve. Neuropsychologia, 47(10), 2015-2028. 10.1016/j.neuropsychologia.2009.03.004

Stern, Y. (2012). Cognitive reserve in ageing and Alzheimer's disease. Lancet Neurology, 11(11), 1006-1012. 10.1016/ S1474-4422(12)70191-6

Sternberg, R. (2006). Psicologia cognitiva (5ª ed.). Porto Alegre: Artmed.

Strauss, E., Sherman, E. M., \& Spreen, O. (2006). A compendium of neuropsychological tests: Administration, norms, and commentary. Oxford University Press, USA.

Strout, K. A. \& Howard, E. P. (2012). The six dimensions of wellness and cognition in aging adults. Journal of Holist Nursing, 30(3), 195-204. 10.1177/0898010112440883

Werlang, B. S. G. (2012). Autópsia Psicológica, importante estratégia de avaliação retrospectiva Psychological Autopsy: an important strategy for retrospective evaluation. Ciência e Saúde Coletiva, 17(8), 1955-1957.

Yesavage, J. A., Brink, T. L., Rose, T. L., Lum, O., Huang, V., Adey, M., \& Leirer, V. O. (1982-1983). Development and validation of a geriatric depression screening scale: A preliminary report. Journal of Psychiatric Research, 17(1), 37-49. 10.1016/0022-3956(82)90033-4

Zortea, B., Gautério-Abreu, D. P., Santos, S. S. C., Silva, B. T. D., Ilha, S., \& Cruz, V. D. (2015). Cognitive assesment of elderly people in outpatient care. Northeast Network Nursing Journal, 16(1), 123-131. 10.15253/21756783.2015000100016

Nota:

Artigo com apoio do Edital 1/2017 para periódicos científicos vinculados a Programas de Pós-Graduação filiados à ANPEPP.

Dados dos autores:

Luis Henrique Paloski - Doutorando, Faculdade Meridional IMED

Adriano Medeiros da Cunha - Psicólogo, Pontifícia Universidade Católica do Rio Grande do Sul.

Camila Rosa de Oliveira - Doutora, Faculdade Meridional.

Marianne Farina - Doutoranda, Pontifícia Universidade Católica do Rio Grande do Sul.

Valéria Gonzatti - Doutoranda, Pontifícia Universidade Católica do Rio Grande do Sul.

Elisa Arrienti Ferreira - Doutoranda, Pontifícia Universidade Católica do Rio Grande do Sul.

Manoela Ziebell de Oliveira - Doutora, Pontifícia Universidade Católica do Rio Grande do Sul.

Irani Iracema de Lima Argimon - Doutora, Pontifícia Universidade Católica do Rio Grande do Sul.

Tatiana Quarti Iragaray - Doutora, Pontifícia Universidade Católica do Rio Grande do Sul.

Endereço para correspondência:

Luis Henrique Paloski

Pontifícia Universidade Católica do Rio Grande do Sul

Av. Ipiranga, 6681, prédio 11, sala 939

90619-900, Porto Alegre, RS., Brasil

$<$ luishenriquepaloski@gmail.com>

Recebido em: 08.02.2017

Aceito em: 22.05.2017 